\title{
Geological and tectonic implications obtained from first seismic activity investigation around Lembang fault
}

\author{
Afnimar $^{1 *}$, Eko Yulianto ${ }^{2}$ and Rasmid ${ }^{3}$
}

\begin{abstract}
The Lembang fault located at northern part of populated Bandung basin is the most conspicuous fault that potentially capable in generating earthquakes. The first seismic investigation around Lembang fault has been done by deploying a seismic network from May 2010 till December 2011 to estimate the seismic activities around that fault. Nine events were recorded and distributed around the fault. Seven events were likely to be generated by the Lembang fault and two events were not. The events related to the Lembang fault strongly suggest that this fault has left-lateral kinematic. It shows vector movement of Australian plate toward NNE might have been responsible for the Lembang fault kinematic following its initial vertical gravitational movement. The 1-D velocity model obtained from inversion indicates the stratigraphy configuration around the fault composed at least three layers of low Vp/Ns at the top, high $\mathrm{Vp} / \mathrm{s}$ at the middle layer and moderate $\mathrm{Vp} / \mathrm{s}$ at the bottom. In comparison with general geology of the area, top, mid and bottom layers may consecutively represent Quaternary volcanic layer, pre-Quaternary water-filled sedimentary layer and pre-Quaternary basement. Two eastern events related to minor faults and were caused by a gravitational collapse.
\end{abstract}

Keywords: Pre-quaternary sedimentary rock; Left-lateral faulting; New segment of Lembang fault

\section{Backgorund}

The Bandung Basin is a plateau surrounded by several mountains and active volcanoes. The basin morphology formed due to tectonic and volcanic activity during the Quaternary. Thick lake sediments were deposited in the basin during the Late Quaternary. These deposits might conceal several buried faults. The Lembang fault is located at the northern part of the Bandung basin where The Bandung City is located. Administratively, this basin is located in West Java province and surrounded by several mountains, which are associated with mapped faults (Figure 1). Bandung is a densely populated city in Indonesia. It is surrounded by several faults that may potentially be earthquake sources. Regarding to disaster risk reduction, it is important to reveal the seismicity in this area. We studied seismic activities around the Lembang Fault, the most conspicuous fault in the basin.

\footnotetext{
* Correspondence: afnimar.1987@gmail.com

'Seismological Laboratory, Faculty of Mining and Petroleum Engineering, Bandung Institute of Technology (ITB), Ganesha 10 Street, West Jawa 40132, Indonesia

Full list of author information is available at the end of the article
}

The formation of the Lembang Fault was explained by Dam [1]. In the Early-Middle Quaternary, the west-east trending highland with the oldest volcanoes of the Burangrang-Sunda complex (including Tangkubanperahu Volcano), the volcanic ridges and peaks in the northeastern Lembang area, and most of the volcanic terrain between Bandung and Sumedang were formed. Following the build up of the Sunda volcano, a gravitational collapse, due to the loading of enormous amounts of volcanic deposits on ductile marine sediments, caused thrust faults and diapiric structures in the near surface strata of the northern foot slopes (Van Bemmelen, [2]). Rifting associated with catastrophic sector failure eruptions destroyed the volcanic cones, while the depressurization of the main magma reservoir led to normal faulting and the formation of the Lembang fault. This fault, with an impressive scarp, was studied by Tjia [3], who concluded both older dip-slip and younger strike-slip displacement had occurred.
(C) 2015 Afnimar et al.; licensee Springer. This is an Open Access article distributed under the terms of the Creative Commons Attribution License (http://creativecommons.org/licenses/by/4.0), which permits unrestricted use, distribution, and reproduction in any medium, provided the original work is properly credited. 


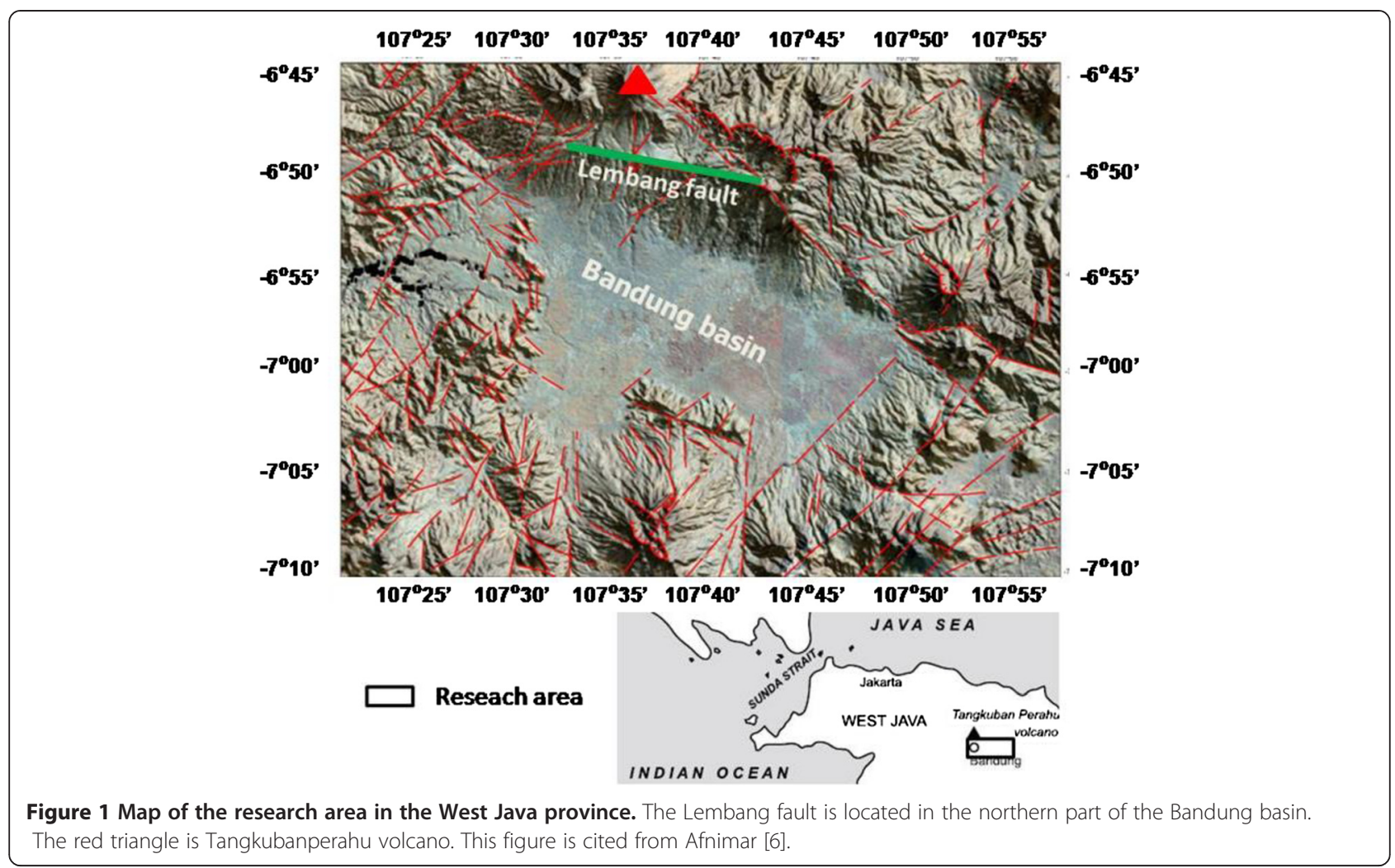

Recent paleoseismological study shows several evidences of near past activities of the fault. This study concluded that within last $2 \mathrm{kyrs}$, the Lembang fault has been capable in producing earthquake of $\sim 6.8$ and 6.6 magnitude at about 2 and 0.5 kyrs BP respectively [4]. Accordingly, the fault may be capable in triggering earthquakes of comparable magnitudes in the future.

The Bandung Basin as seen in (Figure 1) will act to amplify seismic waves if the Lembang fault generates an earthquake. The level of amplification is depended on sediment thickness. The sediment structure has been investigated using the microtremor array method [5], which showed that the deepest basement reaches about $3.5 \mathrm{~km}$. Seismic wave amplification in the Bandung Basin was simulated by Afnimar [6] using Haskell's method.

Although paleoseismological study of the Lembang fault shows evidences of significant faultings at the past, the seismicity around the Lembang fault is generally very low and mostly not sensed by people. In July 21, 2011, a M 2.9 earthquake and in August 28, 2011, a M3.3 earthquake (BMKG report) were those among others sensed by people and brought spotted damages to houses in the vicinity of the fault zone, and were recorded by the local seismic network around the fault. Until now, detail seismic investigation of the Lembang fault has not been done. In this study, we investigate it using hypocenter relocation (including 1-D velocity determination) and focal mechanism analysis.

\section{The data}

A temporal seismic network (Figure 2) has been deployed around the Lembang fault by BMKG from May 2010 till

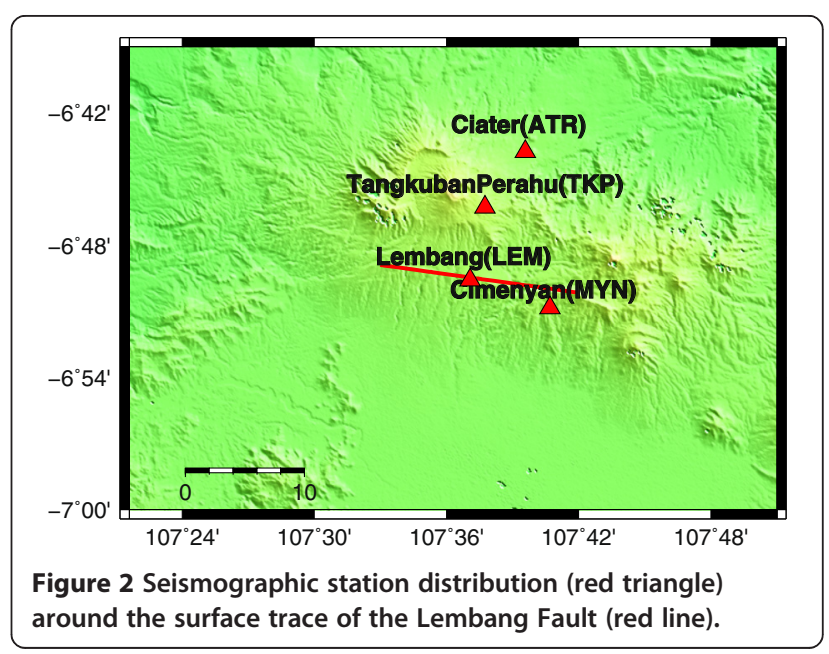


December 2011. Four Taurus-Nanometrics seismometers are installed at Lembang (LEM), Cimenyan (MYN), Parongpong and around Cibodas. In the middle of 2010, two seismometers were moved from Parompong and Cibodas to Tangkubanperahu Volcano (TKP) and Ciater (ATR), due to avoid noises from farming activities. During these two years, the network has recorded about 15 earthquakes. This research will only analyze events those that originated from the area around Lembang.

One example of the recorded seismic waveform is shown in (Figure 3 ). The $\mathrm{P}$ wave arrival picking is based on its onset that is clearly visible on the seismograms. It is more difficult to find the $\mathrm{S}$ wave onset, especially in the seismogram from station MYN. Fortunately, the horizontal components of seismograms from stations LEM, TKP and ATR show clear S-wave onsets. The picking of $\mathrm{S}$ waves from these three stations could be used as a guidance to find the $S$ wave phase on the seismogram from station MYN. There are one or two phases observed at station MYN before the
$S$ wave arrival. These phases are probably produced from reflections due to complicated structure north of this station.

\section{Methods}

The first step that should be done on earthquake analysis is earthquake location determination. An earthquake location includes a geographical position, a depth and an origin time. The origin time can be determined using what is called a Wadati diagram [7]. The result from the Wadati diagram is one input of the gradient inversion method that is usually used to locate one event. This is the reason for this method is often used as a single event determination (SED). The velocity structure used in this step is guessed from geological structures around the Lembang fault. This inversion method was first introduced and applied by Geiger [8] and called the Geiger method of earthquake location. The result of the SED method should be recalculated due to the structure heterogeneity around the Lembang fault. A joint Hypocenter Location (JHD) method was first proposed by

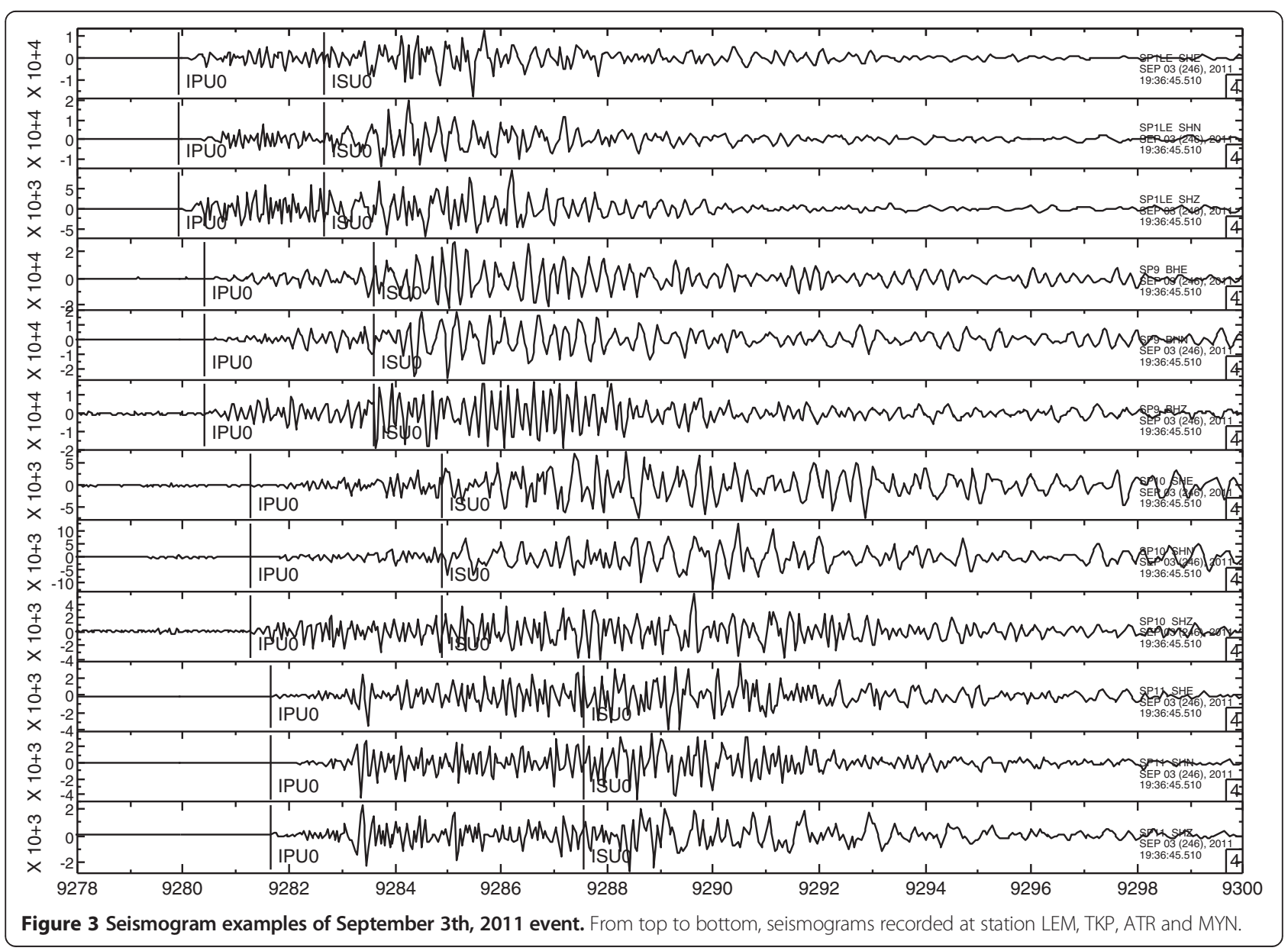


Douglas [9] to accommodate the residual time at all stations (station correction) caused by velocity heterogeneity of station locations. Kissling et al. [10] extended the JHD method by including a 1-D velocity model as a parameter in inversion.

To estimate the earthquake mechanism, the moment tensor inversion developed by Kuge [11] is applied in this research to estimate the earthquake mechanism. The optimum moment tensor solution is reached by best fitting between observation and synthetic waveforms through inversion process. The synthetic waveforms are calculated by the extended reflectivity method developed by Kohketsu [12]. The velocity structure where that synthetic waveform calculated is $1-\mathrm{D}$ velocity model result from the JHD. The observation velocity waveforms are cut from $\mathrm{P}$-wave onset to $\mathrm{S}$-wave pulse (5 to $10 \mathrm{~s}$ windowing) and are filtered in $0.075-0.25 \mathrm{~Hz}$ using SAC. Sometime for small event, the velocity waveforms of an event are integrated to get the displacement waveforms to reduce the ringing pattern. We show the original outputs related to the highest magnitude event (Figure 4) and to the lowest one (Figure 5). The fitting between observation waveforms and synthetic ones for all events are varies that is identified by variance value (see Figures 4 and 5). Although there is variation of variance values, the synthetic waveforms still cover the trend of the observation ones. The observation waveforms recorded at station TKP look like noisy and can not fit well with synthetic waveforms. Even some events, for example the event in (Figure 5), the observation waveforms can not be identified at this station. The reason should be caused by the structure heterogeneity around Tangkubanperahu Volcano.

\section{Earthquake location and focal mechanism}

The relocated SED hypocenters obtained using the JHD method for all events listed in (Table 1) and their double-couple solutions of moment tensor results listed in (Table 2) are plotted in (Figures 6 and 7). Most of them seem to have relationship with the Lembang fault. Only two very shallow events (at a depth less then $5.0 \mathrm{~km}$ ) are located to the east part and therefore it is unlikely to have relationship with the Lembang fault.

The events related to the Lembang fault strongly suggest that this fault has left-lateral kinematic with

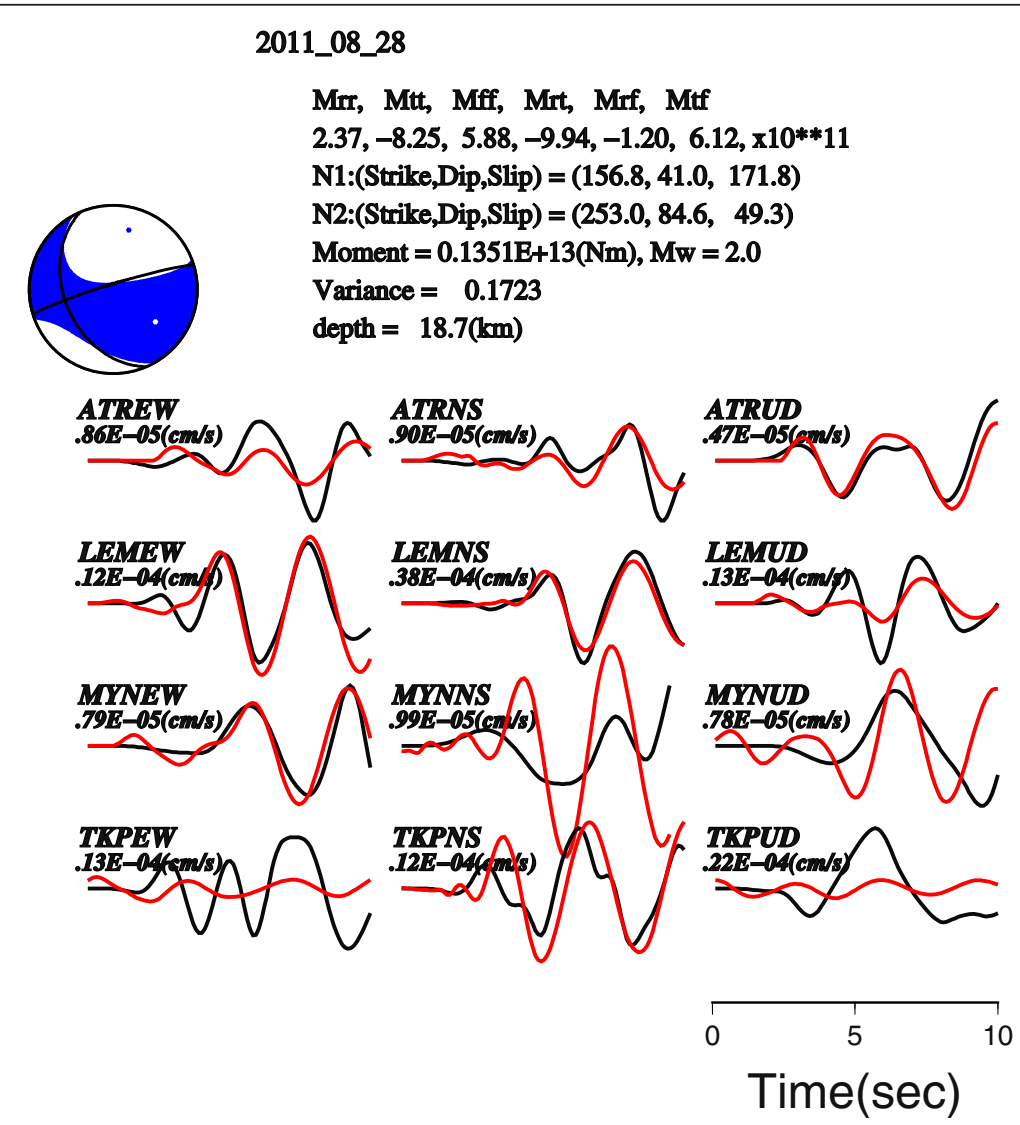

Figure 4 The complete output of moment tensor solution of the 28 August 2011 event (highest magnitude earthquake). The black lines are observation waveforms and the red lines are calculation ones. 


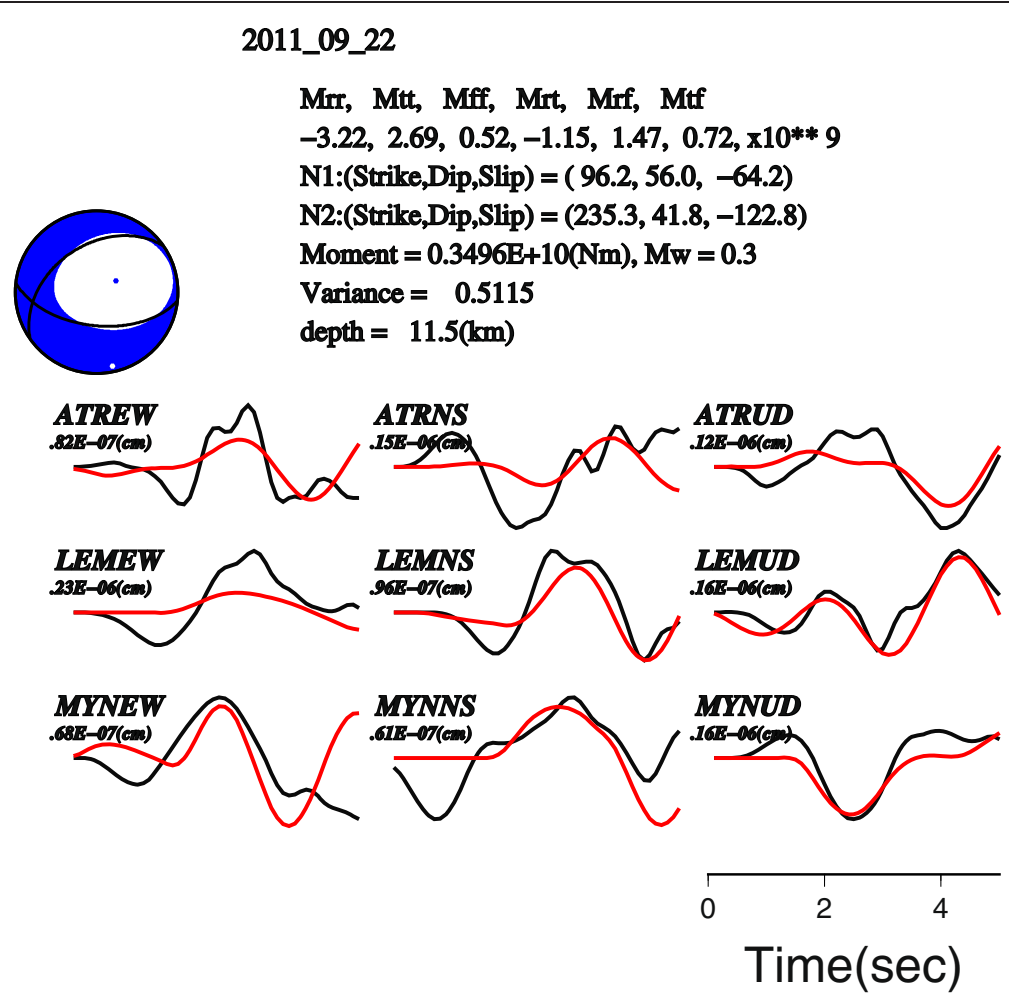

Figure 5 The complete output of moment tensor solution of the 22 September 2011 event (lowest magnitude earthquake). The black lines are observation waveforms and the red lines are calculation ones.

slightly trust component. The NNE vector movement of Australian plate (e,g. [13]) might have been responsible for the kinematic reversion of the Lembang fault following its initial vertical gravitational movement. Initial movement of east segment of the fault might have been triggered by cataclysmic eruption of Sunda Volcano as explained by Van Bemmelen [2], and that of west segment by cataclysmic eruption of ProtoTangkubanperahu Volcano as deducted by Nossin et al. [14] but subsequent movements should have been triggered by slow strain accumulation from NNE movement of the Australian plate. It could be deducted here that although the Lembang Fault was kinematically formed as a normal fault, it has kinematically been reverted to a left-lateral strike-slip fault with a trust (dip-slip) component. This could be an explanation for the occurrence of slicken-lines with horizontal component reported by Tjia (1968).

The widely recognized surface trace of the Lembang fault stretches for about $15 \mathrm{~km}$ in the ESE - WSW

Table 1 Hypocenter parameters of all events

\begin{tabular}{llllll}
\hline Event number & Year/Month/Date & Origin time (UTC) & Latitude (South) & Longitude (East) & Depth (km) \\
\hline 1 & $2011-07-21$ & $22: 46: 44.73$ & $-6.8011^{\circ} \pm 0.002 \mathrm{~km}$ & $107.7505^{\circ} \pm 0.002 \mathrm{~km}$ & $03.87 \pm 0.005$ \\
2 & $2011-08-10$ & $08: 35: 33.96$ & $-6.7860^{\circ} \pm 0.003 \mathrm{~km}$ & $107.4728^{\circ} \pm 0.007 \mathrm{~km}$ & $14.03 \pm 0.021$ \\
3 & $2011-08-28$ & $09: 05: 53.40$ & $-6.7889^{\circ} \pm 0.003 \mathrm{~km}$ & $107.5056^{\circ} \pm 0.001 \mathrm{~km}$ & $17.74 \pm 0.001$ \\
4 & $17: 49: 56.60$ & $-6.7523^{\circ} \pm 0.004 \mathrm{~km}$ & $107.5453^{\circ} \pm 0.004 \mathrm{~km}$ & $27.31 \pm 0.011$ \\
5 & $2011-09-03$ & $22: 11: 19.99$ & $-6.7870^{\circ} \pm 0.001 \mathrm{~km}$ & $107.5087^{\circ} \pm 0.001 \mathrm{~km}$ & $19.75 \pm 0.000$ \\
6 & $2011-09-03$ & $17: 03: 17.66$ & $-6.8242^{\circ} \pm 0.002 \mathrm{~km}$ & $107.6933^{\circ} \pm 0.011 \mathrm{~km}$ & $10.46 \pm 0.005$ \\
7 & $2011-09-22$ & $20: 42: 18.08$ & $-6.7935^{\circ} \pm 0.001 \mathrm{~km}$ & $107.6922^{\circ} \pm 0.006 \mathrm{~km}$ & $02.26 \pm 0.015$ \\
8 & $2011-09-27$ & $20: 33: 39.03$ & $-6.7633^{\circ} \pm 0.005 \mathrm{~km}$ & $107.5418^{\circ} \pm 0.003 \mathrm{~km}$ & $25.46 \pm 0.007$ \\
9 & $2011-09-28$ & $00: 51: 34.99$ & $-6.7481^{\circ} \pm 0.004 \mathrm{~km}$ & $107.4971^{\circ} \pm 0.000 \mathrm{~km}$ & $29.60 \pm 0.010$ \\
\hline
\end{tabular}


Table 2 Fault plane and seismic moment of all events obtained from moment tensor inversion

\begin{tabular}{|c|c|c|c|c|}
\hline Event number & Fault plane I (strike/dip/rake) & Fault plane II (strike/dip/rake) & $M_{0}(\mathrm{Nm})$ & $\mathrm{M}_{\mathrm{w}}$ \\
\hline 1 & $133.2 / 89.9 /-112.1$ & $43.1 / 22.1 /-0.2$ & $0.55 \times 10^{12}$ & $\overline{1.8}$ \\
\hline 2 & 273.2/87.3/37.6 & $181.1 / 52,4 / 176.5$ & $0.32 \times 10^{12}$ & 1.6 \\
\hline 3 & 253.0/84.6/49.3 & $156.8 / 41.0 / 171.8$ & $6.12 \times 10^{11}$ & 2.0 \\
\hline 4 & 284.7/84.2/34.9 & $190.7 / 55.3 / 172.9$ & $0.15 \times 10^{12}$ & 1.4 \\
\hline 5 & 283.8/85.5/41.9 & 189.7/48.2/173.9 & $0.30 \times 10^{12}$ & 1.6 \\
\hline 6 & 235.3/41.8/-122.8 & $96.2 / 56.0 /-64.2$ & $0.35 \times 10^{10}$ & 0.3 \\
\hline 7 & 201.5/60.2/-111.5 & $59.8 / 36.1 /-57.4$ & $0.54 \times 10^{10}$ & 0.4 \\
\hline 8 & $294.4 / 78.7 / 8.4$ & 202.7/81.8/168.6 & $0.40 \times 10^{11}$ & 1.0 \\
\hline 9 & $273.3 / 89.7 / 36.2$ & 183.1/53.8/179.6 & $0.69 \times 10^{12}$ & 1.8 \\
\hline
\end{tabular}

(Figure 1) with a strike of $\sim \mathrm{N} 282^{\circ} \mathrm{E}$. Events $2,3,4,5,8$ and 9 are distributed in an area west of this wellknown surface trace of the Lembang Fault (Figure 6). Because the hypocenters for these events lie at some distance from this surface trace, they appear at first glance to be unrelated to the Lembang fault. But the strikes of the fault planes designated (I) in (Table 2) are quite consistent with the strike of the Lembang fault. Their vertical distribution along the cross section $A B$ indicated in (Figure 7) also aligns well with a possible westward extension of the Lembang fault, assuming the near-vertical dip that is consistent with the estimated fault planes. For these reasons, we interpret these events to be related to the Lembang fault. This implies that the Lembang fault extends at least $10 \mathrm{~km}$ further westward than would be inferred from its surface trace. Consequently, there should be a fault line extends slightly westward from the end point of

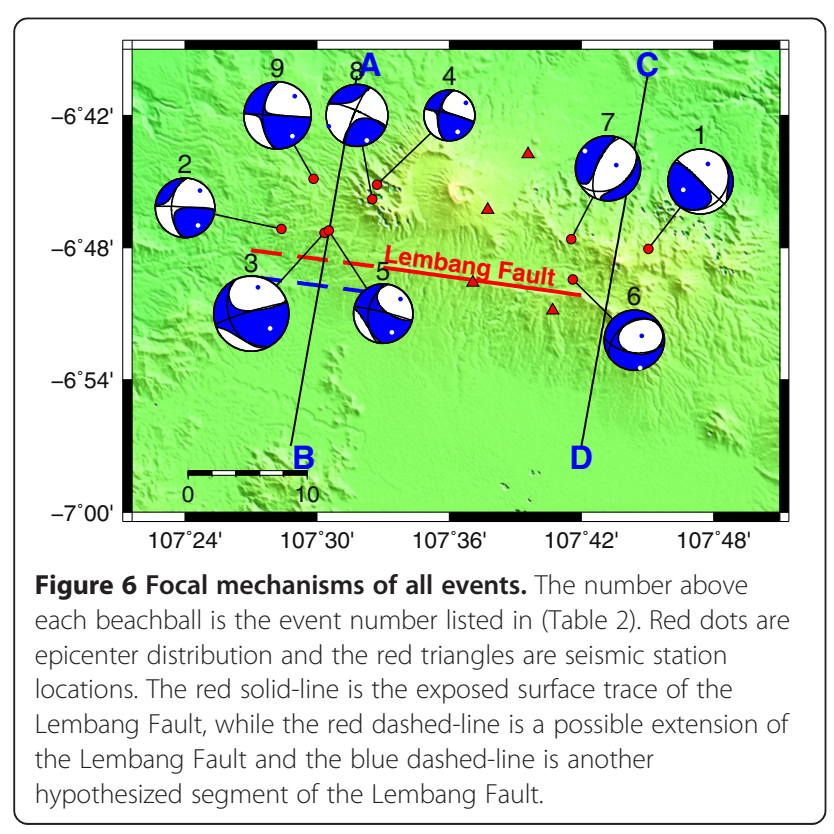

Lembang fault. This line could be connected to the existing Lembang fault line and morphologically unexposed (dash-line in Figure 6), or it is a different segment of Lembang fault. Based on regional mapping of morphological features, Horspool et al. [15] notified that at the west-end, the fault line is slightly hooked southward showing a horsetail shape. At the south end of this horsetail shape, another possible fault line stretches almost parallel to the Lembang fault where to the north of this line, events $2,3,4,5,8,9$ are distributed. Therefore, we simply interpret that those events were related to this line that is probably another segment of Lembang fault. From these events, we also can state the geometry of Lembang fault. The average strike is about $277^{\circ}$ which is not so different with surface trend line of $282^{\circ}$, the dip is about $85^{\circ}$ and the rake is about $35^{\circ}$.

Result of GPS measurement of Australian plate slip azimuth yielded an average direction of $\sim \mathrm{N} 20-21^{\circ} \mathrm{E}$ [13]. As the general trend of Lembang fault is $\mathrm{N} 282^{\circ} \mathrm{E}$ (Figure 8), therefore the possible kinematic of the fault should have a left-lateral component. The general direction of pressure axis of all events distributed at the western part of the Lembang fault gives evidences to this idea. The average direction of those events is oblique left-lateral faulting with an average pressure axis of $\mathrm{N} 225.3^{\circ} \mathrm{E}$. This may explain the development of the horsetail shape feature between the existing Lembang fault line and the proposed additional line as a transtensional jog. A new schematic geometry of Lembang fault is presented in (Figure 9).

Events those occurred at the eastern part of Lembang fault are distributed in an area where a graben structure had developed during cataclysmic eruption of Sunda Volcano at about 0.2-0.18 Ma [16]. A pair of E-W oriented faults at the north and south bordered this graben [16]. The south border is then recognized as the east segment of Lembang fault. This initial geological structure influences further local tectonic 

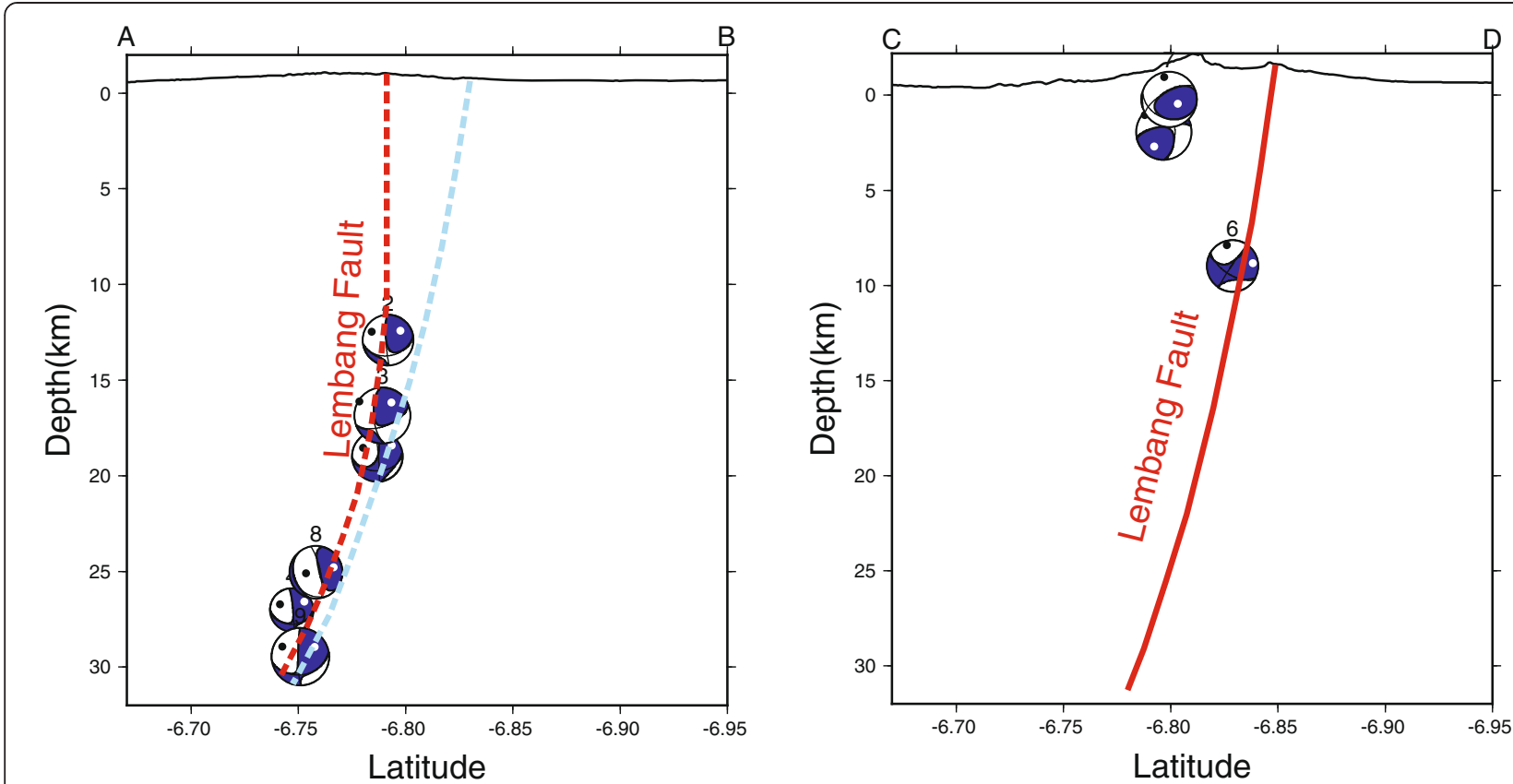

Figure 7 Cross section of all focal mechanisms along line AB (left) and along line CD (right) in (Figure 6). The red dashed-line is a possible extention of the Lembang Fault, while the blue dashed-line is another hypothesized segment of the Lembang Fault, and the red solid-line is related to Lembang Fault.

evolution as indicated by events 1,6 , and 7 . Focal mechanisms of these events, particularly events 1 and 7 , suggest apparent normal faulting component (gravitational collapses). Events 1 and 7 might be related to faulting of minor faults in the graben area to the north of Lembang fault. Due to its position (Figure 7) and its focal mechanism, event 6 might be related to the eastern part of Lembang. Obvious left-lateral component of event 6 is consistent with those of events distributed at the west

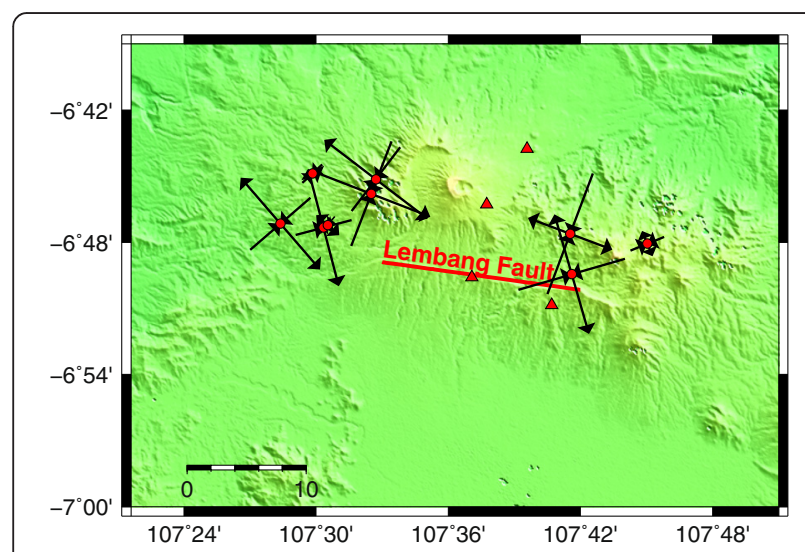

Figure 8 Horizontal components of pressure (outward-pointing arrow couple) and tension vectors (inward-pointing arrow couple). of Lembang fault and thus strongly suggesting leftlateral kinematic of Lembang fault.

\section{Velocity structure}

The 1-D structure including $\mathrm{P}$ and $\mathrm{S}$ wave velocities (Table 3) obtained from the JHD method is presented as graphics of Depth vs. Velocity (Figure 10). Interpretation is given in this figure. Three layers can be distinguished from $\mathrm{Vp}$ graphic i.e. high $\mathrm{Vp}$ values at depths deeper than $6 \mathrm{~km}$ with an exception of that at $18 \mathrm{~km}$, moderate

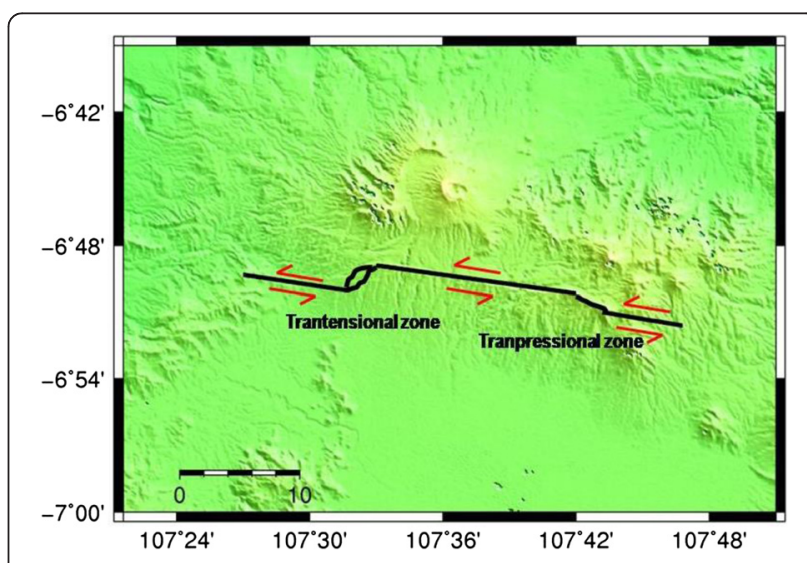

Figure 9 A modified schematic geometry of the Lembang Fault. 
Table 3 Velocity model used in SED and its velocity obtained from JHD

\begin{tabular}{|c|c|c|c|c|c|}
\hline \multirow[t]{2}{*}{ Depth (km) } & \multicolumn{2}{|l|}{ SED } & \multicolumn{3}{|l|}{ JHD } \\
\hline & $V p(\mathrm{~km} / \mathrm{s})$ & $V s(\mathrm{~km} / \mathrm{s})$ & $V p(\mathrm{~km} / \mathrm{s})$ & $V s(\mathrm{~km} / \mathrm{s})$ & $V p / V s$ \\
\hline 0.5 & 2.90 & 2.20 & 2.474 & 2.014 & 1.228 \\
\hline 1.0 & 3.00 & 2.30 & 3.627 & 2.123 & 1.708 \\
\hline 2.0 & 3.00 & 2.30 & 3.653 & 2.040 & 1.791 \\
\hline 3.0 & 3.40 & 2.40 & 3.636 & 1.839 & 1.977 \\
\hline 5.0 & 3.40 & 2.40 & 3.681 & 2.155 & 1.708 \\
\hline 8.0 & 4.30 & 2.50 & 4.442 & 2.879 & 1.543 \\
\hline 18.0 & 4.50 & 2.60 & 3.728 & 2.385 & 1.563 \\
\hline 20.0 & 5.00 & 2.90 & 4.391 & 2.094 & 2.097 \\
\hline 22.0 & 5.04 & 2.92 & 4.503 & 2.516 & 1.790 \\
\hline
\end{tabular}

$\mathrm{Vp}$ at depths from $\sim 6$ to $\sim 0.75 \mathrm{~km}$, and low Vp at depth shallower than $0.75 \mathrm{~km}$. The range of high, moderate and low Vp values are higher than 4.0, 3.0-4.0 and 2.0$3.0 \mathrm{~km} / \mathrm{s}$ respectively. Two layers can be distinguished from Vs graphic i.e. high Vs at depths deeper than $6 \mathrm{~km}$ and low Vs at depths shallower than $6 \mathrm{~km}$. The range of high and low Vs values is higher and lower than $2.5 \mathrm{~km} / \mathrm{s}$ respectively. Two layers can be distinguished from $\mathrm{Vp} / \mathrm{Vs}$ graphic i.e. high $\mathrm{Vp} / \mathrm{Vs}$ at depths deeper than $0.75 \mathrm{~km}$ and low $\mathrm{Vp} / \mathrm{Vs}$ at depth shallower than $0.75 \mathrm{~km}$. The range of high and low $\mathrm{Vp} / \mathrm{Vs}$ values is above and below 1.5, respectively. Accordingly, the stratigraphy configuration around the fault can be deducted composing of three layers i.e. high $\mathrm{Vp} / \mathrm{Vs}$ with high $\mathrm{Vp}$ and $\mathrm{Vs}$ at the bottom (less than $6 \mathrm{~km}$ ), high $\mathrm{Vp} / \mathrm{Vs}$ with moderate $\mathrm{Vp}$ and low $\mathrm{Vs}$ at the middle $(6-0.75 \mathrm{~km})$, and low $\mathrm{Vp} / \mathrm{Vs}$ with low $\mathrm{Vp}$ and low Vs at the top (less than $0.75 \mathrm{~km}$ ). The top boundary of this layer is probably at a depth between 0.5 to $1 \mathrm{~km}$ indicated by prominent decreases of $\mathrm{Vp} / \mathrm{Vs}$ and $\mathrm{Vp}$. It is assumed that this boundary is at $0.75 \mathrm{~km}$. The lower boundary is probably at a depth between 5 to $8 \mathrm{~km}$ depths as indicated by prominent decreases of Vs and $\mathrm{Vp}$. This lower boundary is assumed at $6 \mathrm{~km}$. Vs are relatively low in the top and middle layers with a subtle fluctuation.

Low Vp/Vs with low $\mathrm{Vp}$ in the top layer may correlate with large aspect ratio of water content in pores of rocks. Takei [17] report that the water-filled pores have

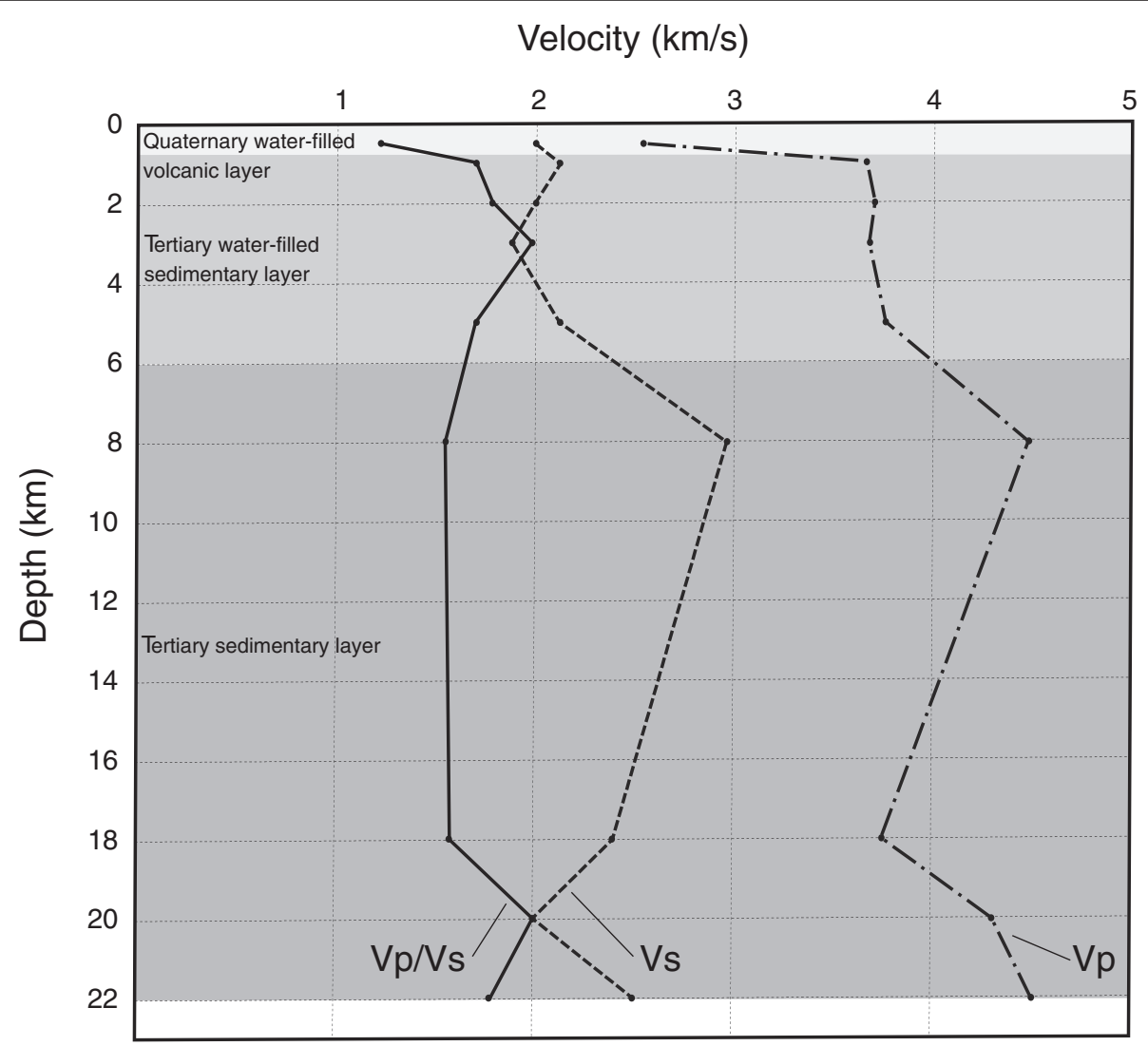

Figure 10 Graphics of Vp/Vs, Vp and Vs, interpreted layers based on Vp/Vs, Vp and Vs (grey colours) and its comparison to general stratigraphy of the study area. 

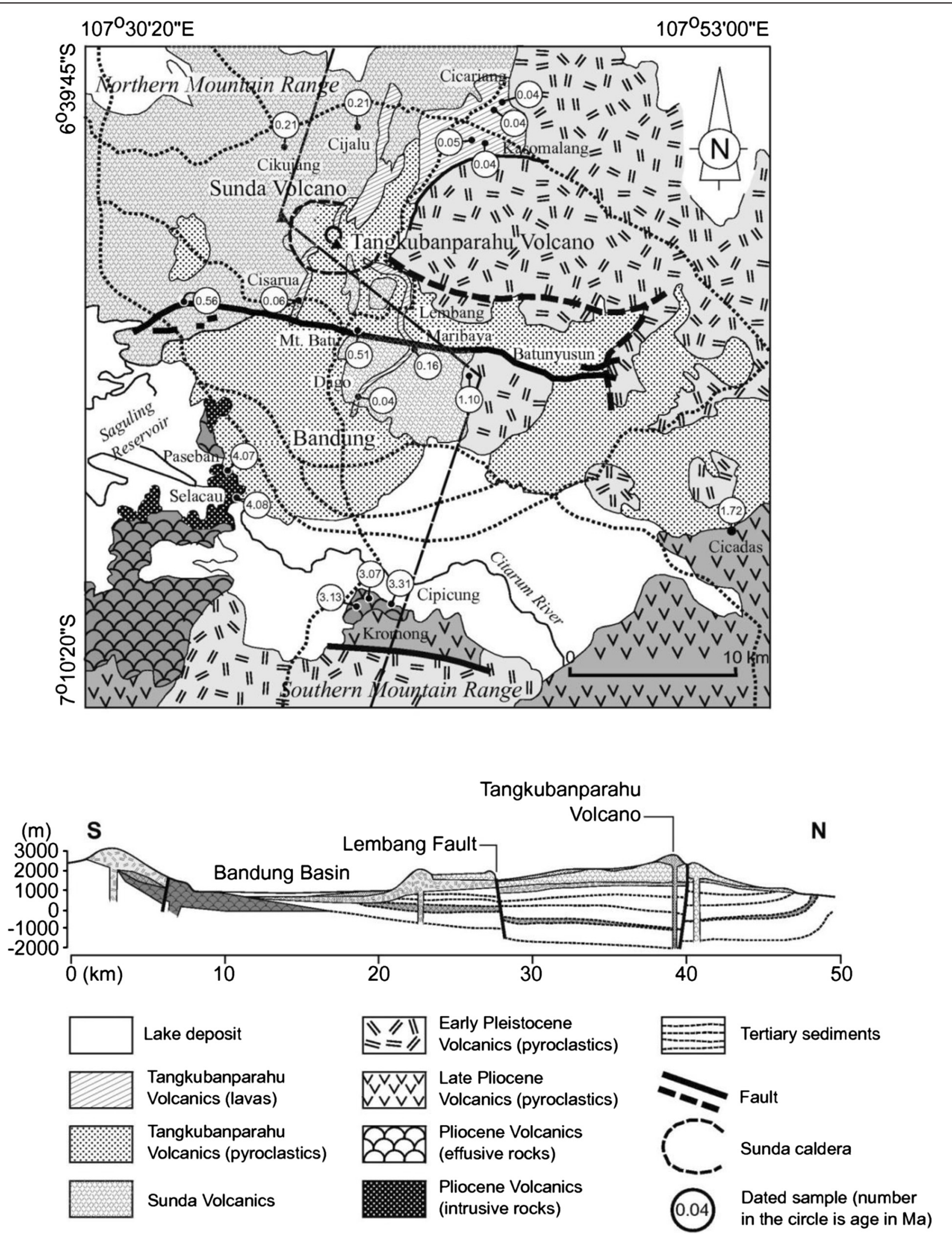

Figure 11 (See legend on next page.) 
(See figure on previous page.)

Figure 11 A modified geological map from Sunardi\& Kimura [17] and Horspool et al. (2011). The Lembang fault line was identified by Horspool et al. (2011) based on morphological features on SRTM digital elevation model of ca. $90 \mathrm{~m}$ grid, showing a length of more than $30 \mathrm{~km}$ excluding the segment identified in this study. The schematic north-south longitudinal stratigraphic profile of the Bandung basin and its adjacent area inferred from geological map, showing Quaternary and pre-Quaternary rock units and their boundary at about $1 \mathrm{~km}$ depth.

a different effect on seismic velocity and Poisson's ratio, which depends on the shape of the pores. Water-filled pores of a small aspect ratio decrease seismic velocity with increasing Poisson's ratio. Water-filled pores of a large aspect ratio, however, can lower Poisson's ratio slightly with decreasing seismic velocity. From this perspective, high Vp/Vs with moderate $\mathrm{Vp}$ and low Vs in the middle layer may indicate smaller aspect ratio of water content of this layer compared to that of the top layer. Lower $\mathrm{Vp} / \mathrm{Vs}$ with high $\mathrm{Vp}$ and Vs in the bottom layer may indicate smallest aspect ratio of water content compared to that in the middle and top layers.

In comparison with general geology of the study area (Figure 11), the top layer should represent Quaternary volcanic layer. The middle and bottom layers should represent Tertiary sedimentary layer or basement according to Satake and Harjono [5].

The station corrections obtained from the JHD method are tabulated in (Table 4). The negative station correction at LEM is observed to occur on bedrock and the positive ones are those on sedimentary or weathering rocks. This means the waves arrived earlier at stations on bedrocks than those on sediment or weathering rocks. Pujol [18] obtained minus value correction related to high velocity anomalies and vice versa from data of Loma Prieta, California, mainshockaftershock sequence. Our result shows similar indication to that of Loma Prieta. The minus value at LEM is related to outcrop of igneous rock (high velocity anomalies) along Lembang fault. The plus ones at TKP, MYN and ATR are related to the volcanic zone (low velocity anomalies).

\section{Conclusions}

From this investigation, stratigraphy of the study area has been revealed based on $\mathrm{Vp}$, Vs and $\mathrm{Vp} / \mathrm{Vs}$, consisting

Table 4 Station corrections obtained from JHD

\begin{tabular}{lcc}
\hline Station & $\Delta \mathbf{t}_{\mathbf{v p}}(\mathbf{s e c})$ & $\Delta \mathbf{t}_{\mathbf{v s}_{\mathbf{s}}}(\mathbf{s e c})$ \\
\hline LEM & 0.000 & -0.884 \\
TKP & 0.324 & 0.000 \\
ATR & 0.455 & 0.202 \\
MYN & 0.460 & 0.239 \\
\hline
\end{tabular}

of three layers. In a perspective of aspect ratio of water content, the top layer with low $\mathrm{Vp} / \mathrm{Vs}$, low $\mathrm{Vp}$ and low $\mathrm{Vs}$ is composed of rocks with largest aspect ratio of water content. The bottom layer with high $\mathrm{Vp} / \mathrm{Vs}$, high $\mathrm{Vp}$ and high Vs is composed of rocks with smallest aspect ratio of water content. In comparison with general geology of the area, the top layer should represent the Quaternary volcanic layer, and the middle and bottom layers should represent the Tertiary sedimentary layer.

The source mechanism of earthquakes along the Lembang fault is left-lateral faulting. All western events are probably related to a new segment of the Lembang fault. This new segment is maybe developed by pressure of Australian plate indicated by horsetail feature. Two shallow eastern events are related to the minor faults and caused by a gravitational collapse.

\section{Competing interests}

The authors declare that they have no competing interests.

\section{Authors' contributions}

A picked again on seismograms, reprocessed earthquake relocation, reprocessed focal mechanism estimation and construct the manuscript. EY supports geological interpretation. $R$ provided all seismogram data and did preliminary processing. All authors read and approved the final manuscript.

\section{Acknowledgements}

We thank Prof. Koketsu from Earthquake Research Institute, The University of Tokyo for his helpful advices. We also thank two reviewers for their constructive comments. Many thanks Prof. Satake from Earthquake Research Institute, The University of Tokyo for his critical review on content and writing of manuscripts.

\section{Author details}

'Seismological Laboratory, Faculty of Mining and Petroleum Engineering, Bandung Institute of Technology (ITB), Ganesha 10 Street, West Jawa 40132, Indonesia. ${ }^{2}$ Research Center of Geotechnology, Indonesian Institute of Sciences, Komplek LIPI Gd. 70, JI Sangkuriang, Bandung 40135, Indonesia. ${ }^{3}$ Meteorology, Climatology and Geophysical Agency (BMKG), Jl. Angkasa I No. 2, Jakarta 13920, Indonesia.

Received: 6 August 2014 Accepted: 2 February 2015

Published online: 07 March 2015

\section{References}

1. Dam MAC (1994) The late quartenary evolution of the Bandung basin, West Java, Indonesia, Vrije Universiteit, Amsterdam

2. Van Bemmellen RW (1949) The Geology of Indonesia, Vol. IA General Geology, The Hague

3. Tjia HD (1968) The Lembang Fault, West Java. Geologie En Mijnbouw 47(2):126-130 
4. Yulianto E (2011) Understanding the Earthquake Threat to Bandung from the Lembang fault, Australia-Indonesia Facility for Disaster Reduction (AIFDR) Project Report, Jakarta, $22 \mathrm{pp}$

5. Satake K and Harjono H (2012) Multi-disciplinary hazard reduction from earthquake and volcanoes in Indonesia, Final Report, JST-JICA-RISTEK-LIPI, 165.

6. Afnimar (2014) Estimation of SH-wave amplification in the Bandung basin using Haskell's method. J Eng Technol Sci 46:93-101

7. Wadati K (1933) On the traveltime of earthquake waves. Part II, Geophys Mag (Tokyo) 7:101-111

8. Geiger L (1910) Herdbestimmungbei Erdbebenaus den Ankunftszeiten. Nachrichten vonder Königlichen Gesellschaft der Wissenschaftenzu Göttingen, Mathematisch-Physikalische Klasse, pp. 331-349. 1910. (translated to English by F. W. L. Peebles and A. H. Corey: Probability method for the determination of earthquake epicenters from the arrival time only, Bulletin St.Louis University 8, pp. 60-71

9. Douglas A (1967) Joint hypocenter determination. Nature 215:47-48

10. Kissling E, Ellworth WL, Eberhart-Phillips D, Kradolfer U (1994) Initial reference models in local earthquake tomography. J Geophys Res 99:19635-19646

11. Kuge K (1999) Automated determination of earthquake source parameters using broadband strong-motion waveform data, EOS. Trans Am Geophys Un 80:F661

12. Kohketsu K (1985) The extended reflectivity method for synthetic near-field seismograms. J Phys Earth 33:121-131

13. Chamot-Rooke N, Le Pichon X (1999) GPS determined eastward Sunda land motion with respect to Eurasia confirmed by earthquakes slip vectors at Sunda and Philippine trenches. Earth Planetary Sci Lett 173:439-455

14. Nossin JJ, Voskuil RPGA, Dam RMC (1995) Geomorphologic Development of the Sunda Volcanic complex, West Java, Indonesia, Proceedings of the International Association of Geomorphologist Southeast Asia Conference, Singapore.

15. Horspool N, Natawidjaja D, Yulianto E, Lawrie S, and Cummins P (2011) An Assessment on the use of High Resolution Digital Elevation Models for Mapping Active Faults in Indonesia. Geoscience Australia Professional Opinion. No.2011/XX, 37 pp.

16. Sunardi E, Kimura J (1998) Temporal chemical variation in late Cenozoic volcanic rocks around the Bandung Basin, West Java, Indonesia. J Min Petr Econ Geol 93:103-128

17. Takei Y (2002) Effect of pore geometry on Vp/Ns: From equilibrium geometry to crack. J Geophys Res 107(B2):2043

18. Pujol J (2000) Joint Event Location - The JHD Technique and Application to Data from Local Seismic Network, in Advances in Seismic Event Location, Thurber C, and N Rabinowitz, eds. Kluwer Academic Publishers, pp. 163-204.

\section{Submit your manuscript to a SpringerOpen ${ }^{\circ}$ journal and benefit from:}

- Convenient online submission

- Rigorous peer review

- Immediate publication on acceptance

- Open access: articles freely available online

- High visibility within the field

- Retaining the copyright to your article

Submit your next manuscript at $\gg$ springeropen.com 